\title{
Research Paper \\ The Effect of Acceptance and Commitment Therapy on Emotional Regulation and Coping Strategies in Patients with Generalized Anxiety Disorder
}

\author{
Ashkan FahleKar ${ }^{1}$, Masoume Faal ${ }^{2}$, Forough Zahedzadeh ${ }^{* 3}$, Omid Amani ${ }^{4}$, Mahin Askari ${ }^{5}$ \\ 1. M.A. in Clinical Psychology, Bandar Abbas Branch, Islamic Azad University, Bandar Abbas, Iran \\ 2. M.A. in Family Counseling, South Tehran Branch, Islamic Azad University, Tehran, Iran \\ 3. M.A. in Psychology, Ahvaz Branch, Islamic Azad University, Ahvaz, Iran
}

4. Ph.D. Student of Clinical Psychology, Faculty of Psychology and Educational Sciences, Shahid Beheshti University, Tehran, Iran

5. Assistant Professor, Department of Psychology, Hormozgan University of Medical Sciences, Bandar Abbas, Iran

Citation: FahleKar A, Faal M, Zahedzadeh E, Amani O, Askari M. The effect of acceptance and commitment therapy on emotional regulation and coping strategies in patients with generalized anxiety disorder. Quarterly Journal of Child Mental Health. 2020; 6(4): 253-265.

\section{http://dx.doi.org/10.29252/jemh.6.4.23}

\section{A R T I C L E I N F O}

\section{Keywords:}

Acceptance and commitment therapy, emotional regulation, coping strategies, general anxiety disorder

Received: 21 Apr 2018 Accepted: 23 Oct 2018 Available: 10 Mar 2020

\section{A B S T R A C T}

Background and Purpose: Studies have shown that cognitive emotion regulation and the type of coping strategy are among the factors that are effective in coping with stress and anxiety. The purpose of this study was to investigate the effectiveness of acceptance and commitment therapy on emotion regulation and coping strategies for patients with generalized anxiety disorder

Method: The design of this study was quasi-experimental with pre-test and post-test with control group. The statistical population of the study consisted of all patients with generalized anxiety disorder aged 13 to 15 years referring to Psychology and Counseling Centers in Tehran in 2017. From this papulation, 30 patients were selected using purposeful sampling and were randomly assigned into two experimental and control groups (15 in each group). The experimental group received acceptance and commitment treatment for 8 sessions and the control group did not receive this intervention. Research data were collected using Cognitive Emotion Regulation Questionnaire (Gross \& John, 2003) and coping styles (Jarvis, 1993). Multivariate analysis of covariance was used to analyze the data.

Results: The results showed that acceptance and commitment therapy had a significant effect on the emotion regulation components and coping styles of the experimental group $(\mathrm{P}<0.01)$. Also, the effect size of the cognitive emotion regulation variable was $49 \%$, repression $53 \%$, problem solving factor $79 \%$, and emotion regulation factor $83 \%$.

Conclusion: Based on the findings, it can be concluded that the commitment and acceptance treatment method teaches people how to deal with events purposefully, effectively and efficiently, and thus helps them to better understand their capacities and abilities to respond and to employ better ways to overcome stressful situations.

\footnotetext{
* Corresponding author: Forough Zahedzadeh, M.A. in Psychology, Ahvaz Branch, Islamic Azad University, Ahvaz, Iran.

E-mail addresses: Foroughzahed@yahoo.com
} 


\title{
تأثير درمان مبتنى بر يذيرش و تعهد بر تنظيم هيجانى و راهبردهاى كنار آمدن مبتلايان به اختلال اضطراب فراكير
}

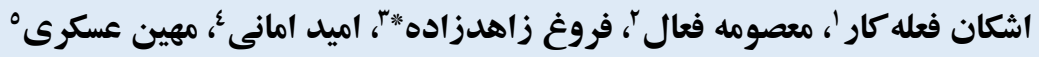

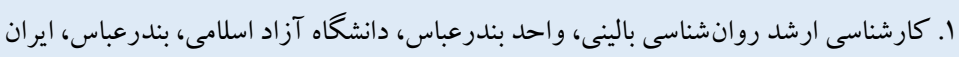

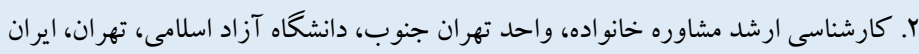

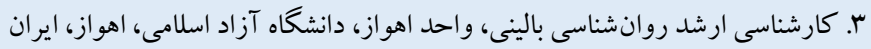

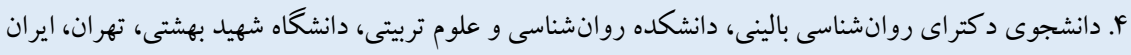

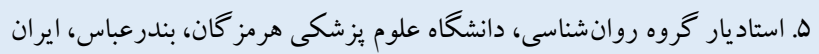

\section{ج)}

زمينه و هدف: مطالعات انجام شده نشان دادهاند كه تنظيم هيجان به شيوه شناختى و نوع راهبرد كنار آمدن مورد استفاده، از جمله عواملى

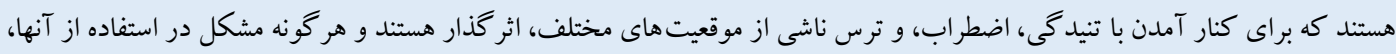

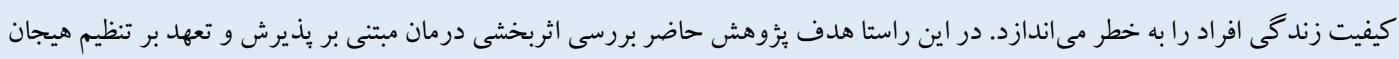

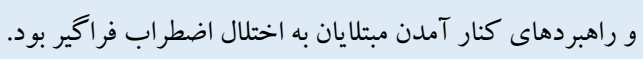

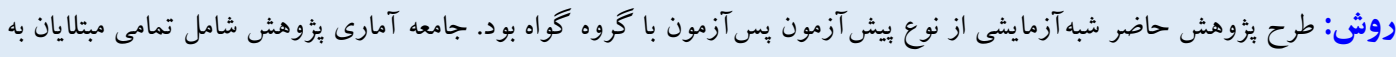

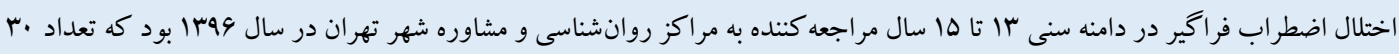

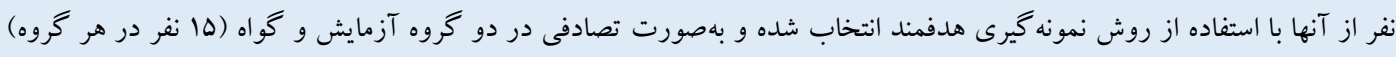

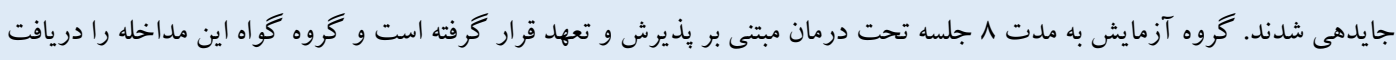

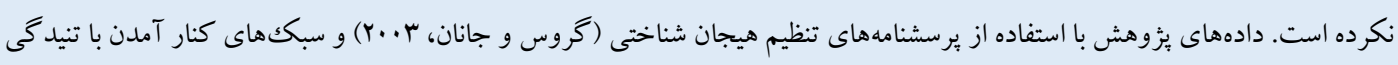

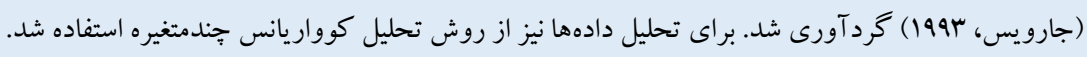

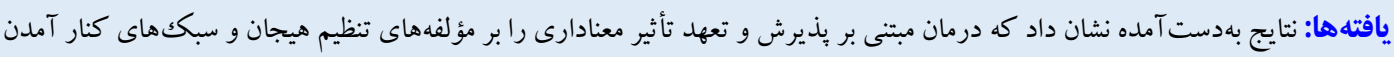

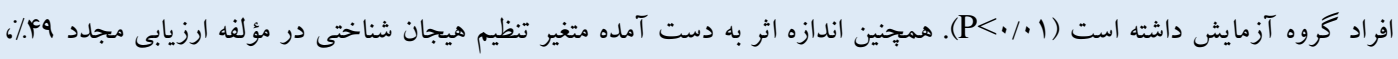

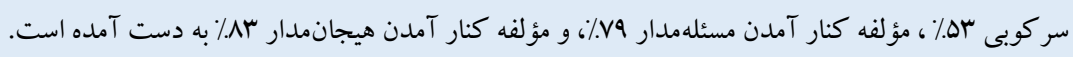

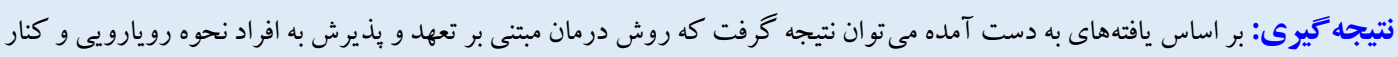

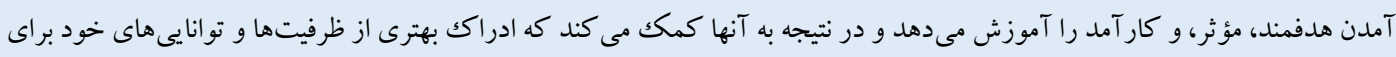

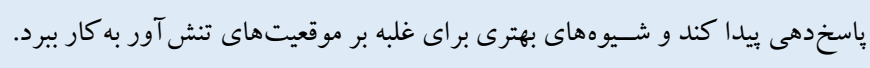

مشخصات مقاله

كليدوازهها:

درمان مبتنى بر بذيرش و تعهل،

تنظيم هيجان، راهبردهاى كنار آمدن، اختلال اضطر اب فراكير
دريافت شده:

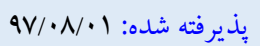
منتشر شده: PN/IY/Y

** نويسنده مسئول: فروغ زاهدزاده، كارشناسى ارشد روانشناسى بالينى، واحد اهواز، دانشكاه آزاد اسلامى، اهو از، ايران.

Foroughzahed@yahoo.com

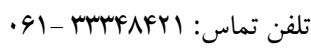


ضـعيفى را خو اهد داشـت ( •(). در اين راسـتا از جمله عو املى كه براى كنار آمدن با تنيدكى ‘ُ، اضـطر اب، و ترس ناشسى از موقعيتهاى مختلف تأثير گذار اسـت، تنظيم هيجانه اسـت. تنظيم هيجان شامل ايجاد افكار و رفتـارهايى اسـتـت كه به افراد آكاهى مى دهد جهه نوع هيجانى دارند، ته هنگحام اين هيجان در آنها يديد مى آيد، و جّكونه بايد آنها را ابراز كنند. هيجانها داراى كيفيت بالايى هسـتند و مى توانند باعث واكنش مثبت يا منفى در افراد شــوند (11). اكر هيجانها متناسـبـ با موقعيت و شــرايط بـاشـــند، باعث واكنش مثبت مى كردند و در غير اين صــورت، واكنش منفى در يى دارند؛ بنابر اين زمانى كه هيجانها شديد يا طولانى مى شوند و يا با شر ايط منطبق نيستند، بايد تنظيم و مديريت شوند (Y) (I). تنظيم هيجان شامل همه راهبردهاى آكَاهانه و غير آكاهانهاى مى شود كه براى افزايش، حفظ، و كـاهش مؤلفـههـاى هيجانى، رفتارى، و شـــاختى يكك وِاســـخ هيجانى كاربرد دارند و همجينين آموزش تنظيم هيجان به معناى كاهش و مهار هيجانات منفى و نحوه استفاده مثبت از هيجانات است (سا ). بررسى متون و مطالعات انجام شده نشان مىدهند كه تنظيم هيجان شناختى نقش مهمى در بيـامـد اختلالهاى روانشــناختى بازى كرده و عامل مهمى در تعيين سـلامتى و داشـتن عملكرد موفق در تعاملات اجتماعى اسـت (If). همجينين نارسايى در تنظيم هيجان با اختلالات درون نمود مانند افسردكى، انزوى اجتمـاعى، و اضـــر اب؛ و اختلـالات برون نمود مانند بزهكارى و

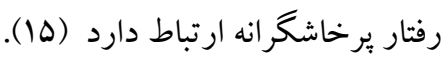

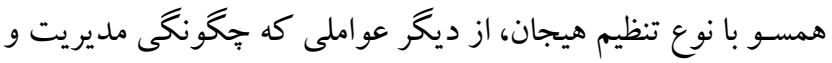
مهار آن محور بحـث و توجه يُزوهشها اسـت، كنار آمدن با تنيدكى 9

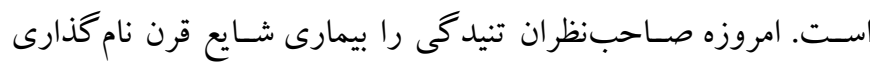
كردهاند (19). تنيد كى عبارت است از مجموع واكنش هاى عمومى انسان نسبت به عوامل سازشنايافته و بيشبينىنشده داخلى و خارجى؛ به طورى كه تعادل و ســازش يافتكى فرد به علت عوامل خارجى و داخلى از ميان برود (IV). وجود تنيد گى غيرقابل اجتناب بوده و مسئله مهم، مديريت و كنـار آمدن با تنيدگى اســت. راهبردهاى كنار آمدن مجموعهاى از تلاشهاى شـناختى و رفتارى فرد اسـت كه در جهت تعبير و تفسـير و

4. Stress

5. Emotion regulation

6. Coping with stress

7. Coping strategies
مقلدمه

نوجوانى دورهاى از تحول اسـت كه با ويز گیىهايى مانند تغييرات سـريع بلوغ، تغيير انتظارات اجتماعى، و تناقضـاتى در نقش همراه اسـت (1). يكى از رايجترين مشكلات روانيزشكى در دوران كودكى و نوجوانى، اختلالات اضـطر ابى اسـت. تمايز بين اختلالات اضـطر ابى با اضطر ابهاى معمول اين دوران، اهميت ويثزاى دارد (Y). طبت گز ارش سازمان سلامت جهانى' بيش از •له ميليون نفر در دنيا به اختلال هاى روانى مبتلا هسـتند. با اين حال آمار مربوط به كسـانى كه مشـكلات روانى دارند (نه در حد اختلال روانى)، بسـيار بيشـتر از اين ميزان اسـت (س) . از بين مشـكلات عمومى سلامت روان، شيوع اضطراب و افسردگى بسيار بالا گزارش شده اسـت. يكى از اختلالات شـايع و مزمن دوران كودكى و نو جوانى اختلال اضـطراب تعميم يافته يا فراگير باسـت (F). اضسطراب فراگير، از جمله اختلالات اسـاسى در آسيبشناسى روانى بوده كه نشانگًان و علائم آن را مى توان بـازتـابدهنـده فر اينـدهـاى اصــلى موجود در تمـامى اختلالات هيجـانى دانســت (ه). مطابق با بنجمين راهنماى تشــخيصـى و آمارى اختلـالـات روانى '، اختلال اضــطر اب فراخير داراى نشــانهايى همبحون نكر انى و اضـطراب بيش ازحد، دشـوارى در مهار نكخرانى، و شكايتهاى روانشناختى و جسمانى (مانند تنش عضلانى، تحريك يذّيرى، بىقرارى، و مشكلات در تمركز و خواب) است (9). مبتلايان به اين نوع از اختلال درباره موضسوعات روزمره زندگىى، نگُرانى مداومى داشـته و به صسورتى يايدار در مورد همه مســائل، دلنخران هســتند؛ بهطورى كه اين نخرانى موجب دشوارى در تغيير توجه از يكك موضوع به موضوع ديكرى شده و زمينهساز اختلال در عملكرد آنها مىشود (V). بررسى هاى صسورت كرفته نشان مى دهد كه اختلال اضطر اب فر اخير

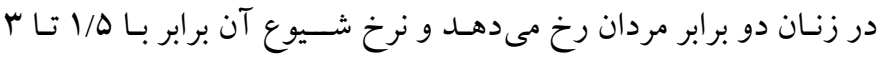
درصسـد اســت (A). در ايران نيز اين اختلال بهعنوان يكى از شــايعترين اختلال هاى روانى شـناخته شده (9) و شيوع يككساله آن در ميان جمعيت

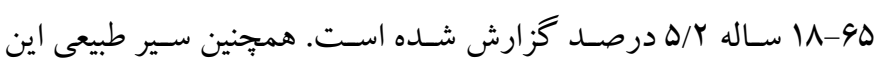

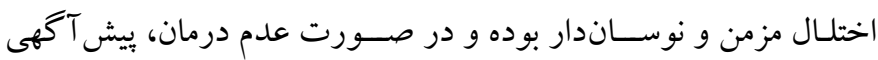

1. World health organization

2. General anxiety disorder

3. Diagnostic and statistical manual of mental disorders 5 th edition (DSM-5) 
هاشمى و سهر ابى (Yr) نيز نشان دادند كه درمان مبتى بر بذيرش و تعهد

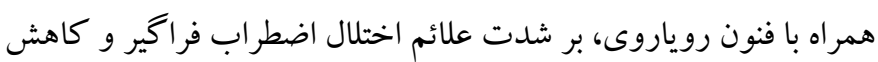

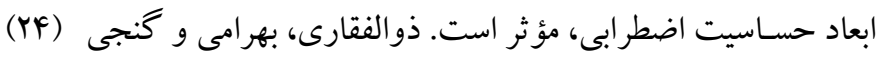
نيز نشان دادهاند كه درمانهاى مبتنى بر بذيرش و تعهل و شناختى رفتارى

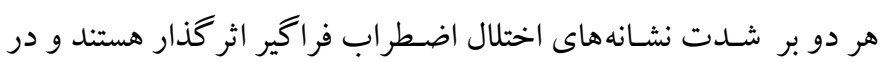

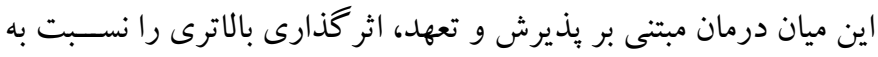

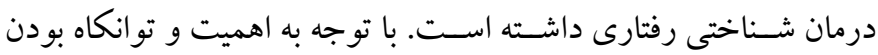

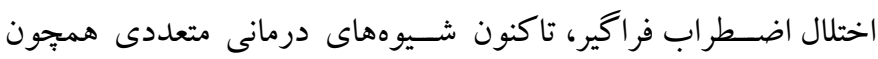

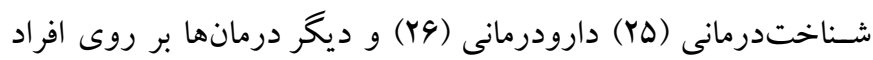

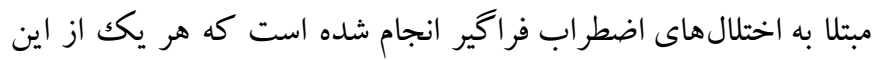

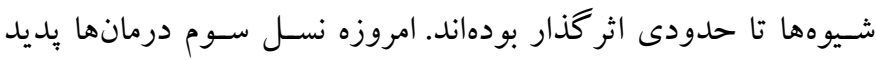

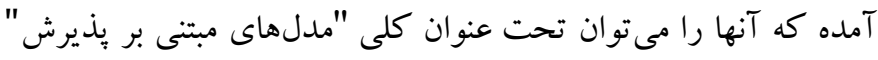

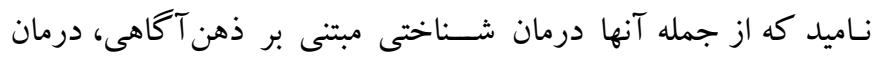

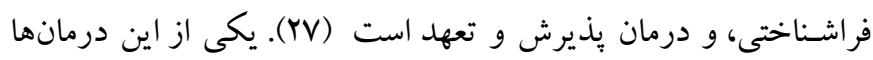

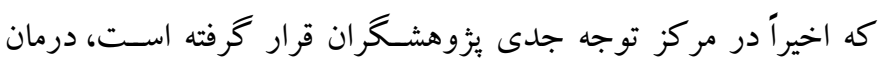

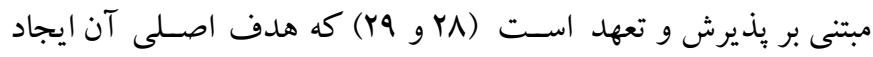
انعطاف يذيرى روانى اسـت؛ يعنى ايجاد توانايى انتخاب عملى در در بين

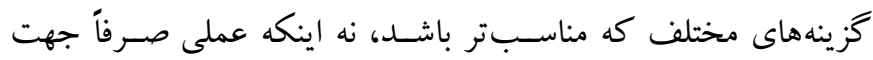

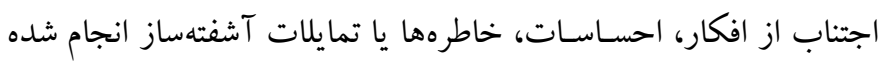
و در حقيقت به فرد تحميل شود (·r). مزيت عمده اين روش نسبت به رواندرمانىهاى ديخر، در نظر گرفتن جنبههاى انخيزشـى بـ به همراه جنبه هاى شـناختى، به جهت تأثير و تدوام بيشتر اثربخشى درمى درمان است

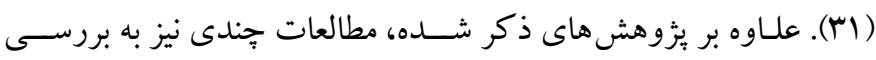

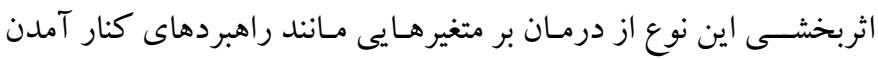

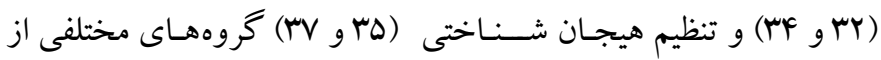
اختلـالـات و بيمارىهاى يرداختهاند. با در نظر داشـتن اهميت مداخله و درمـان اختلـال اضـطر اب فراگير و در نظر گرفتنن اين نكتهـ كـه تاكنون يزروهشهـايى كه به بررسـى اثربخشسى درمان يذيرش و تعهد بر تنظيم

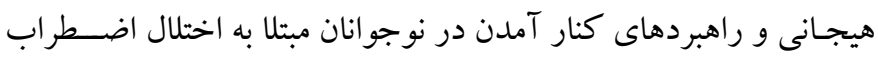

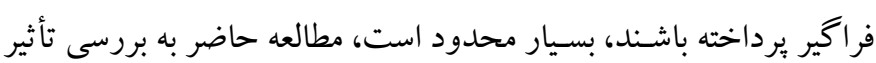

اصلاح يكك وضعيت تنش آور به كار رفته و به كاهش رنج ناشى از آن

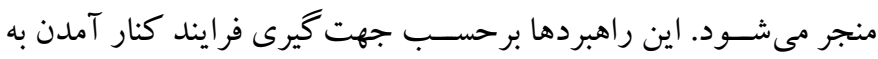

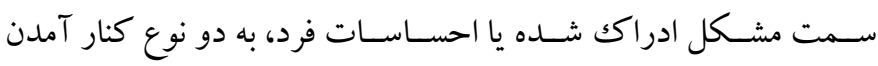

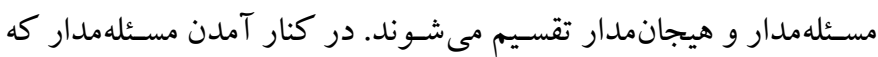

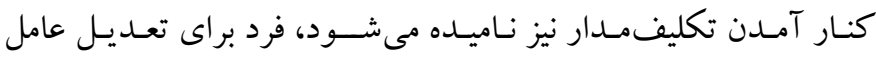
تنش آور و رسيدن به هدف، مستقيماً با موقعيت تنش آور مواجه مى شود؛

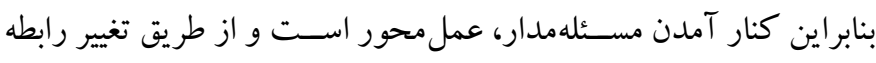

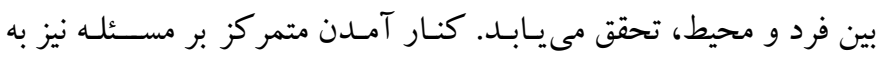

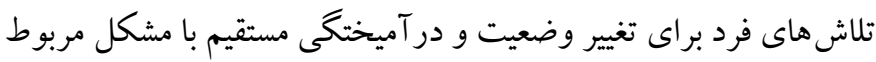

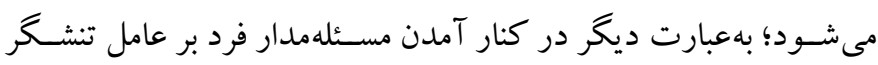

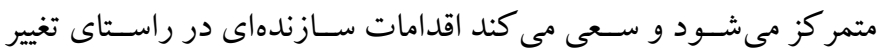

شرايط تنش آور يا حذف آن انجام دهد (1) (1).

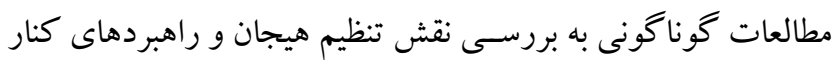

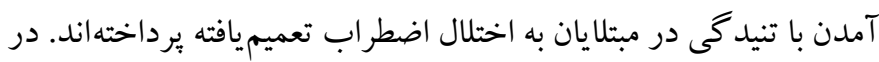

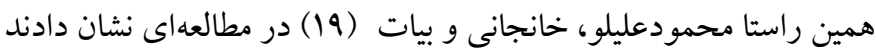
كـه بين راهبردهـاى كنـار آمـدن هيجـانمـدار، راهبردهـاى كنـار آمـدن اجتنابى، و تنظيم هيجان از نوع فرونشـانى دانش آموزان داراى نشـانههاى اختلـال هيجـانى بـا همتـايـان بهنجـار، تفــاوت معنى دارى وجود دارد.

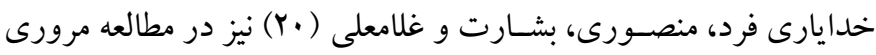

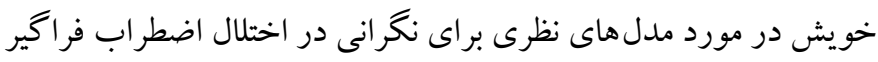

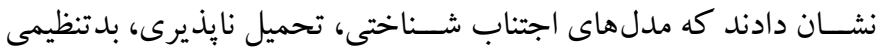

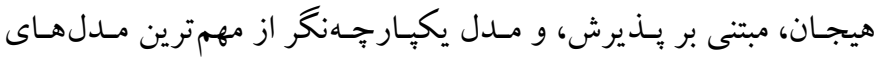

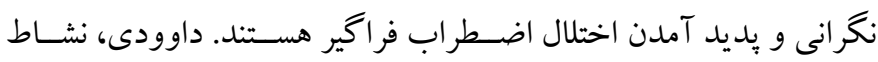

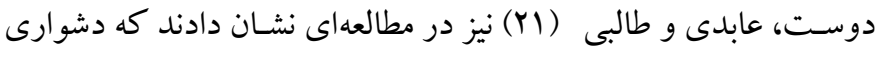

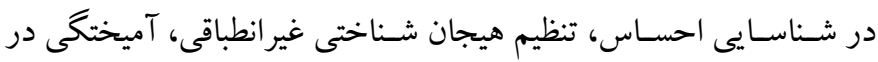

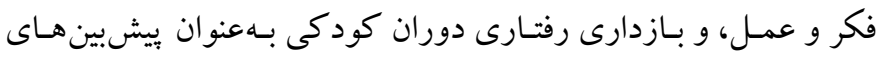

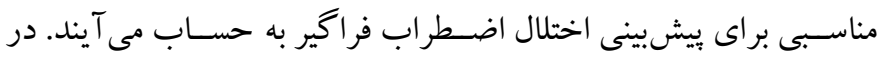

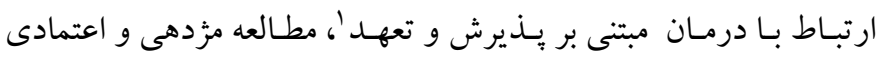

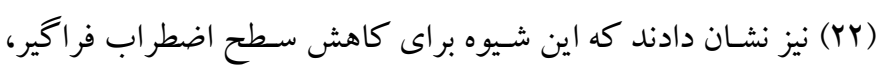

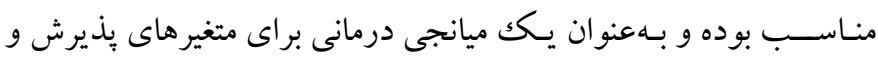

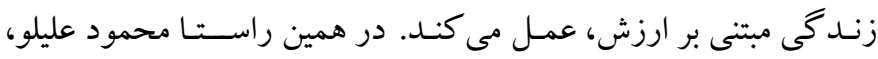




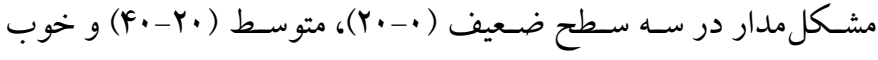

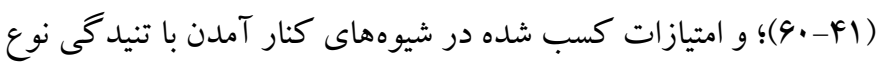
هيجانمدار در سـه سـطح ضسعيف ( •-YM)، متوسـط (سM-49) و خوب (90-94) نمره گذارى شــده و بر اسـاس امتياز كسـب شــده توسـط آزمودنى، نوع شـيوه كنار آمدن به كارگرفته شـده مشـخص مىشـود. ضـريب اعتبار يرسـشــنامه روش هاى كنار آمدن با تنيدكى با آلفاى

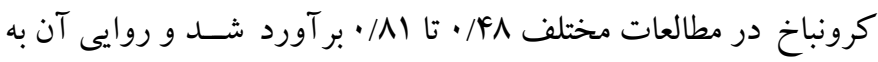
شـيوههاى مختلف مورد تأييد قرار گرفته اسـت (N) . در ايران نيز اين يرســـنامه را اولين بار زهرى (وس) به كار گرفت كه اعتبار محتوايى آن را از طريق تأييد متخصـصـان و بايايى آن نيز با اسـتفاده از آزمون-باز آزمون مجدد به فاصسله يكك ماه در دانشسويان AV/ • به دست آورد. در مطالعه حاضـر نيز اعتبار اين ابزار از طريق آلفاى كرونباخ IN/، به دست آمد كه بيانگر يايايى مطلوب اين مقياس است. r. برسشنامه تنظيم هيجانى بّ" اين برسشنامه توسط گروس و جان در سال r... بهمنظور اندازه گيرى راهبردهاى تنظيم هيجانى تهيه شــده اسـت. اين يرسسنامه مشتمل بر دو زيرمقياس ارزيابى مجدد (شامل و كويه) و فرونشانى هيجانه (شامل \& گ Fويه) است. روش نمره گذارى اين برسشنامه به اين ترتيب اسـت كه سـؤالات ا، له ه، V، ^و • مربوط به زيرمقياس ارزيـابى مجدد و ســؤالات r، F، 9 و 9 مربوط به زيرمقياس فرونشــانى هيجان بوده و شـركت كنندكان باســخ خود راد در يكك مقياس ليكرت ل درجهاى از ا (بهشدت مخالفم) تا V (بهشدت مخالفم) ياسخ مى بهند كه جمع نمرات گويههاى هر خردهمقياس، بيانگر نمرهاى است كه آزمودنى در آن زيرمقياس دريافت كرده اســت. در يثوهش كراس و جان (F. ) همبسـتحى درونى براى زيرمقياس ارزيابى مجدد V9/ • و براى زيرمقياس فرونشانى هيجان س// • بهدست آمده است. همجِنين اعتبار درونى كل اين مقيـاس سل/ • و يـايـايى بـاز آزمـايى آن 99/ • خزارش شــده اســت كه نشاندهنده يايايى قابل قبول اين ابزار است. در ايران، حسينى و خير (FI) اعتبار اين مقياس را با استفاده از آلفاى كرونباخ V9/ • كزارش كردند و ضـرايب همبسـتخى نمره هر كويه را با نمره كل مقياس بين اه| • تا

4. Cognitive reappraisal

5. Expressive suppression
شـــيوه درمـانى يذيرش و تعهد بر تنظيم هيجان و راهبردهاى كنار آمدن نوجوانان مبتلا به اختلال اضطراب فراگير برداخته است.

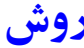

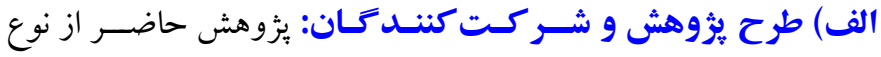
مطالعات شـبه آزمايشى با طرح بيش آزمون يس آزمون با گروه كو اه بود. جامعه آمارى اين يثزوهش شـامل تمامى دختران و يسران نو جو ان مبتلا به

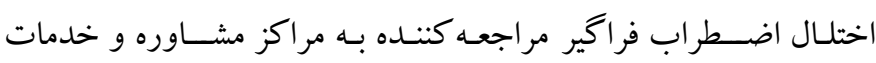
روانشـناسى تهران در سال وهبا بود. نمونه بثزوهش نيز شامل ·ب نفر از جامعه مذكور بودند كه با اســفاده از روش نمونه گيرى هدفمند انتخاب شـده و در دو گرووه آزمايش و كواه جايدهى شدند. افراد نمونه در دامنه

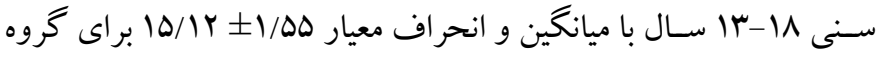

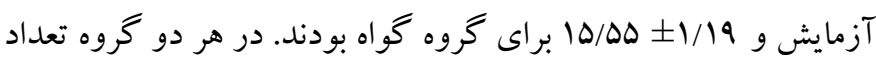

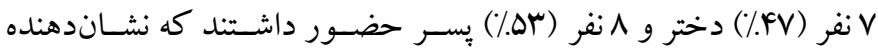
همخنى دو گروه در شاخص هاى سن و جنس بود. شر ايط ورود به مطالعه شـامل تشـيص اختلال اضطر اب فراگير بر مبناى برونده و سابقه بيمارى افراد، قرار داشـتن در محدوده سـنى بين Y ا الى \1 سال، سابقه حداقل I ســال ابتلـا بـه اختلـال، آكـاهى افراد از بيمـارى خويش، و ير كردن فرم

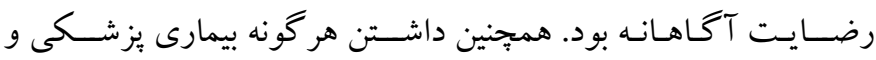
روانيزشــكى ديكر هنگام اجراى مداخله، وجود مشــكلات در بينايى و

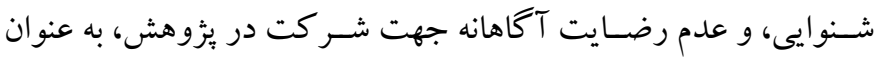
شرايط خروج از مطالعه در نظر گرفته شده بود. ب) ب ابز ار ا. سـياهه شـيوههاى كنار آملدن با تنيدكى ': برسـشـنامه شـيوههاى كنار آمدن با تنيدگى جهت بررسـى ســـك هاى كنار آمدن طر احى شــده و داراى ·F سؤال مربوط به شيوههاى كنار آمدن با تنيدگى مسئلهمدار و هيجانمدار، با اسـتفاده از جدول هشت حيطهاى كنار آمدن جارويس؟ اسـت. كويههاى اين برسشنامه بهصورت ه گزينهاى (هر زز، خيلى كم، كَاهى، اغلب، هميشــه) اسـت كه نمرههاى · تأ أبه اين گزينه ها تعلق مى گيرد و امتيازات كسـب شـده در شيوههاى كنار آمدن با تنيدكى نوع

1. Coping Strategies Questionnaire

2. Jarvis

3. Emotion regulation questionnaire 


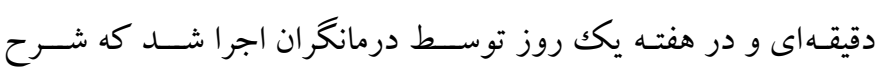

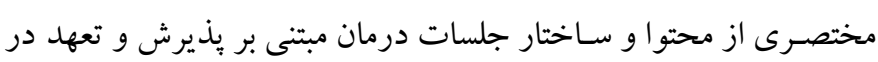
جدول ا گزارش شده است.

191/ به دسـت آوردند كه بيانخر شــاخصهاى روانسـنجى مطلوب يرسشنامه تنظيم هيجانى است.

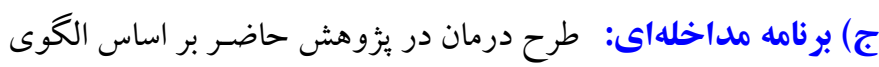

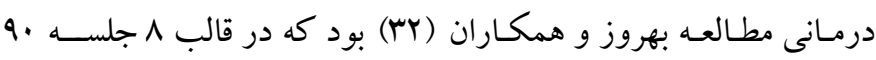
جدول ا: خلاصه محتواى جلسات درمانى

\begin{tabular}{|c|c|c|c|}
\hline محتواى برنامه درمانى & جلسه ال & محتواى برنامه درمانى & جلسه \\
\hline 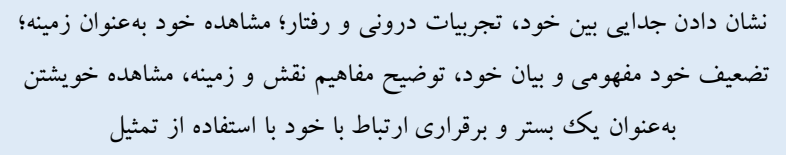 & $\Delta$ & 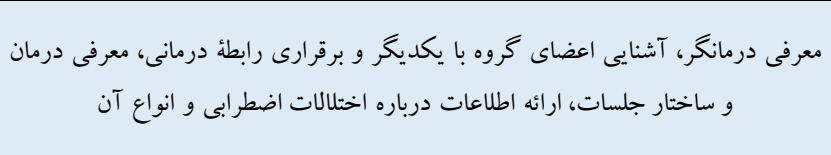 & 1 \\
\hline 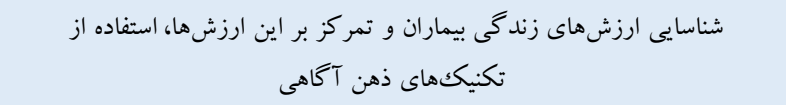 & 4 & ارزيابى ميزان تمايل فرد براى تغيير، بررسى ايجاد درماندگى خللاق & r \\
\hline بررسى ارزشهاى هر يكك از افراد و تعميق مفاهيم قبلى، تفاوت بين ارزشها & v & 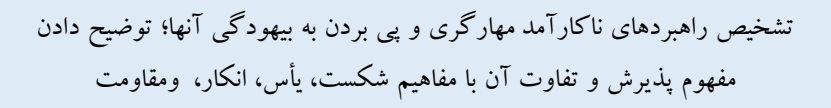 & $r$ \\
\hline تعهد براى عمل به ماهيت تمايل و تعهل، شناسايى طرحهاى رفتارى مطابق با ارزشها و ايجاد درباد & $\wedge$ & 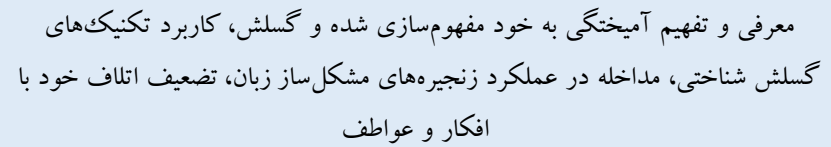 & F \\
\hline
\end{tabular}

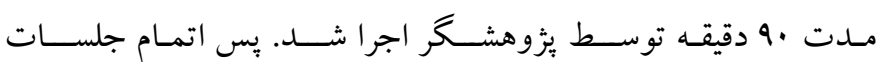

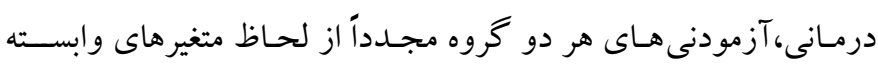
بهعنوان يس آزمون مورد بررسسى قرار گرفتند. در نهايت بهمنظور تحليل

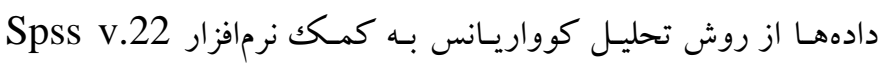
استفاده شد.

\section{مافته}

در جدول r مشخصات توصيفى (ميانگين و انحر اف استاندارد) متغيرهاى يثزوهش در دو ســـطح انـدازه كيرى شــامل بيش آزمون و يس آزمون در كروههاى آزمايش و كو اه ارائه شده است.
د) روش اجرا: يس از كســب مجوزهـاى لـازم علمى و اجرايى جهـت اجر اى اين مطالعه از سـازمانها و مؤسسه هاى مربوط، با مراجعه به مراكز درمـانى از بين افراد داراى ملـاككهاى ورود،، ·ب نفر بهصسورت هدفمند انتخـاب شــده و بهطور تصــادفى در دو گروه آزمايشــى و گروه گو اه جايدهى شــدند. ســـس براى آزمودنى ها در مورد منطق درمان و هدف يثوهشى درمان توضيحاتى داده شد و فرم رضايتنامه درمان توسط آنان تكميـل شـــــ همجينين به آنها اطمينان داده شـــــ كه تمام اطلاعات آنان محر مانه خواهد ماند. در مرحله بعد كه همان بيش آزمون بود، يرسشنامهها

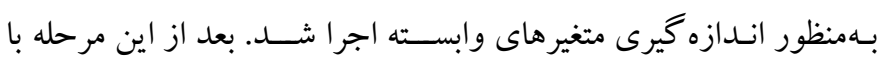
آزمودنى هـاى كروه آزمايشـى بهمنظور شـــر كت در جلســات درمانى قراردادى بسـته شــه و ^ جلسـه درمان به صسورت هفتهاى يكك بار و به

جدول r: يافته ها توصيفى بلدست آمده از تنظيم هيجان شناختى و راهبردهاى كنار آمدن دو كروه آزمايش و كواه

\begin{tabular}{|c|c|c|c|c|c|}
\hline \multicolumn{2}{|c|}{ كروه كواه } & \multicolumn{2}{|c|}{ كروه آزمايش } & \multicolumn{2}{|c|}{ متغير مؤلفه } \\
\hline پֶ آزمون & ييش آزمون & هֶ آزمون & ييش آزمون & & \\
\hline ميانگين (SD) & ميانگين (SD) & ميانگين (SD) & ميانگين (SD) & & \\
\hline $\begin{array}{l}(Y / \Lambda \cdot) 9 / \Delta \Delta \\
(Y / Y Y) \mid Y / F \Delta\end{array}$ & $\begin{array}{l}(Y / N I) \Lambda / Y I \\
(Y / Y \Lambda) \| / Y I\end{array}$ & $\begin{array}{l}(Y / Y Y) \mid Y / Y \\
(Y / V V) V / \Delta G\end{array}$ & $\begin{array}{l}(r / Y \Lambda) V / F \cdot \\
(Y / \Delta I) W / A r\end{array}$ & 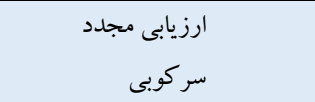 & تنظيم هيجان شناختى \\
\hline $\begin{array}{l}(Y / T I) Y r / .9 \\
(K / Y r) \Delta \Delta / r q\end{array}$ & $\begin{array}{l}(Y / V V) W N / H Y \\
(Y / 9 \Lambda) \Delta \Delta / 9 \Delta\end{array}$ & $\begin{array}{l}(Y / V Q) \mu F / 9 \Delta \\
(F / \Delta Q) \Gamma F / r T\end{array}$ & $\begin{array}{l}(Y / V V) 19 / 09 \\
(\Delta / 90) \Delta 9 / 1 Y\end{array}$ & سبك كنار آمدن هيجانمدار & سبك هاى كنار آمدن \\
\hline
\end{tabular}


نرمـاليتى مورد تأييد گرفت (ه>/P>0/). نتايج آزمون ام باكس نيز فرض

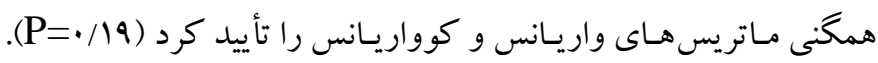

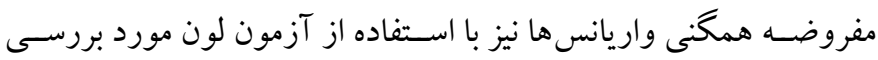
قرار گرفته و تأييد شد (P>0/05) نتايج بررسى همخنى شيب رگر سيون نيز از معنادار نبودن تعامل شـرايط و يِيش آزمون حمايت مى كند، بنابر اين ييشفرضهـاى تحليـل كوواريـانس برقرار بوده و مىتوان از تحليـل

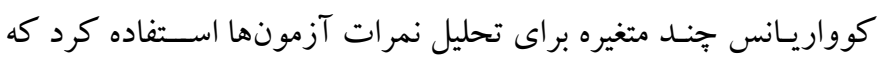
خلاصه نتايج آن در جدول بارائه شده است.
نتـايج حـاصـل از يافته هاى توصـيفى نشــاندهنده تغييرات نمرات

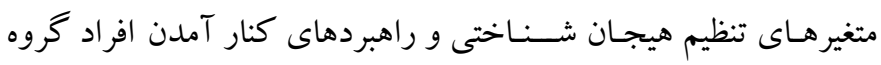

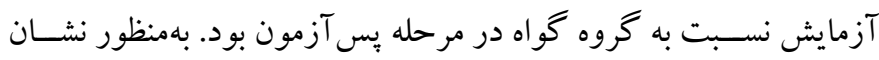
دادن معنى دارى تفـاوت بين نمرات حساصـل از يس آزمون و همجِنين

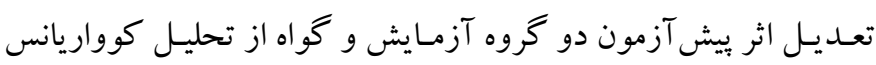

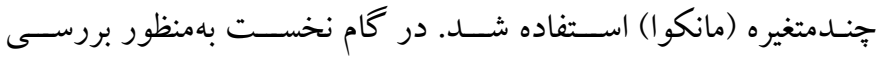
يشيشفرضهاى تحليل كوواريانس خندمتغيره، جهت بررسى طبيعى بودن توزيع متغيرهاى يُزوهش از آزمون شـاييرو ويلكك اسـتفاده شـد كه نتايج

جدول r: نتايج تفاوتهاى بين كروهى براى سبككهاى كنار آمدن با تنيدكى و تنظيم هيجان

\begin{tabular}{|c|c|c|c|c|c|c|c|}
\hline مجذور & سطح معنادارى & $\mathbf{F}$ & ميانكين مجذورات & درجه آزادى & مجموع مجذورات & متغير & \\
\hline.$/ 01$. & $\cdot / \cdots r$ & $r \cdot / v \Delta \Delta$ & $4 / 99$ & $\Delta$ & $1 \cdots / Y F A$ & ارزيابى مجدد & \multirow{4}{*}{ مدل } \\
\hline . & $\cdot / \cdots r$ & $r Y / A \Delta F$ & $\Delta / \cdot \Delta$. & $\Delta$ & $99 / \cdot m V$ & سر كوبى & \\
\hline -/val &.$\cdot \cdot 1$ & IV/TAF & rIG/NVA & $\Delta$ & $1 \cdot \wedge 1 / 94 T$ & مسئلهدار & \\
\hline . /AFT &.$/ . \cdot 1$ & TF/VFD & MIY/.rG & $\Delta$ & $109 \cdot / 11$ & هيجانمدار & \\
\hline - / faf & $\cdot / \cdots$, & rI/MN & Ar/rr. & 1 & Ar/rr. & ارزيابى مجدد & \multirow{4}{*}{ كروه } \\
\hline س & $\cdot / \cdots 1$ & rr/rr5 & $99 / Y 49$ & 1 & $99 /$ YFG & سر كوبى & \\
\hline$\cdot / v 99$ &.$/ \cdots 1$ & $\Lambda r / F I$. & $1.1 r / 991$ & $r$ & $1.1 Y / 991$ & مسئلهمدار & \\
\hline - /ArG & $\cdot / \cdots \cdot 1$ & 1. N/QYS & IrVT/Dra & $r$ & IrVT/OYq & هيجانمدار & \\
\hline
\end{tabular}

تقريبـاً هو درصــــ از تغييرات ارزيـابى مجــدد، سه درصــــ از تغييرات سـر كوبى، V9 درصــد از تغييرات سـبك كنار آمدن مسـئلهمدار، و سر درصــد از تغييرات سـبكك كنار آمدن هيجانمدار، ناشـى از اعمال متغير مستقل يا همان درمان مبتنى بر پذيرش و تعهد است.

\section{بحث و نتيجه كيرى}

اين مطالعه با هدف بررسى تأثير درمان يذيرش و تعهد بر تنظيم هيجان و راهبردهـاى كنـار آمدن نوجوانان مبتلا به اختلال اضــطراب فر اخير انجام شد. يافته هاى بهدست آمده از تجزيهوتحليل دادهها نشان داد كه با كنترل بيش آزمون بين نوجوانان دختر و يسـر مبتلا به اختلال اضــطراب فراخير كروه آزمايش و گروه گواه از لحاظ راهبردهاى كنار آمدن و ابعاد تنظيم هيجان تفاوت معنادارى وجود دارد. در بررسى اثربخشى درمان مبتنى بر يذيرش و تعهد بر تنظيم هيجان شناختى با توجه به ميانخين ارزيابى مجدد هيجان و سـر كوبى هيجان در گروه آزمايش نسـبت به گروه گواه، نتايج

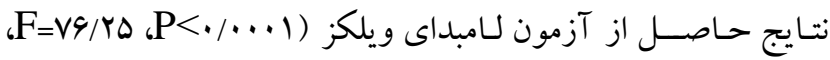
نشان داد كه بين دو گروه حداقل در يكى از متغيرهاى وابسته تفاوت معنى دارى وجود دارد؛ بدين معنا كه با در نظر داشتن بيش آزمون، بين يس آزمون كروهها تفاوت وجود دارد كه نشـان از اثربخشـى برنامه درمانى حداقل بر يكى از متغيرهاى وابســه اسـت. يافته هاى حاصـل از جدول فوق نيز نشاندهنده آن است كه بين ميانخين نمره ارزيابى مجدد و ســركوبى و راهبرد كنـار آمـدن مســئلمدار و هيجانمدار در دو گروه آزمـايش و كواه تفـاوت معنـادارى وجود دارد؛ يعنى درمـان مبتنى بر

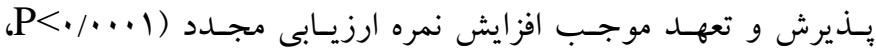

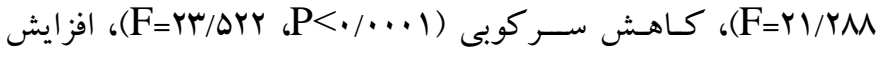
راهبردهاى كنار آمدن مسـئلهمدار ( ( F=人

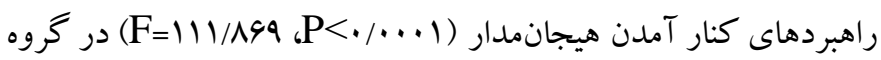
آزمايش و در مرحله يس آزمون شده است. همبجنين مجذور اتا كه اندازه اثر اصسلى در آزمون آمارى تحليل كوواريانس اسـت، نشـان مىدهد كه 
نيسـت؛ كه موضـوع مهم، كاربرد اين تجربيات درونى اسـت و بايد ديد

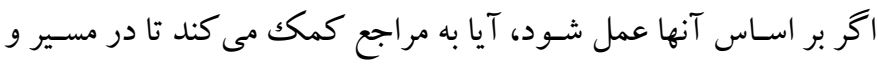
جهت ارزش هاى خود حر كت كند و به هيجانات و احســاسـات بهطور واقعى توجه كند. در متغير راهبردهـاى كنـار آمـدن نيز بـا توجـهـ بـه ميانگين مؤلفههاى

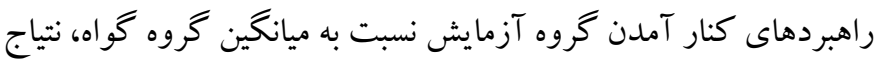

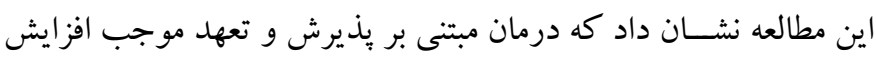

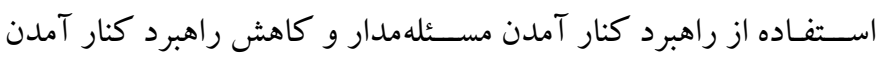

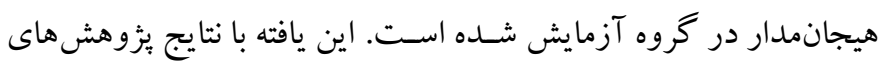

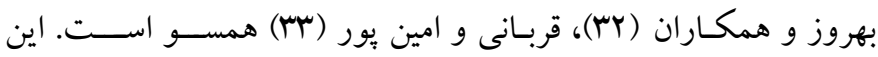

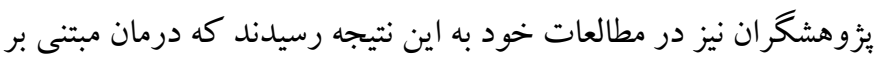

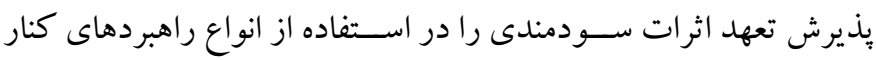

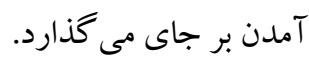

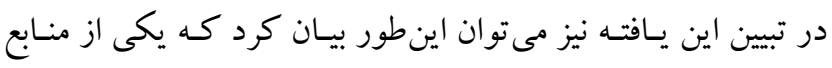

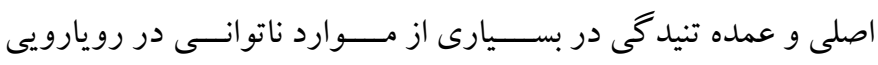

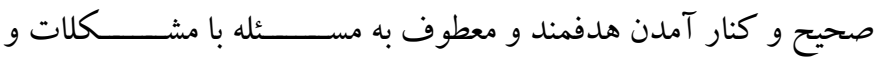

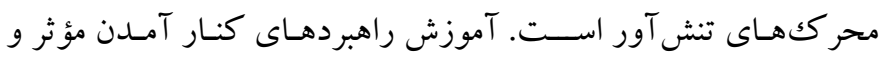

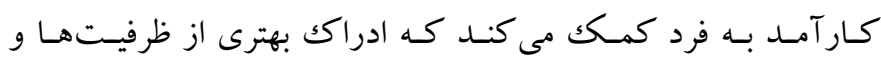
تو انيى هاى خود براى باسخدهى بيدا كند و شـيوههاى بهترى بر ایى غلبه

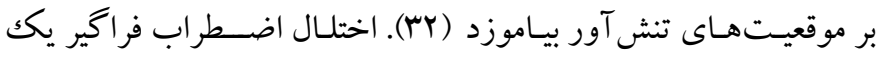

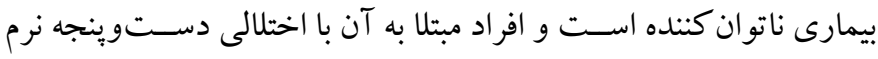

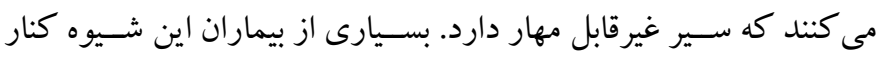

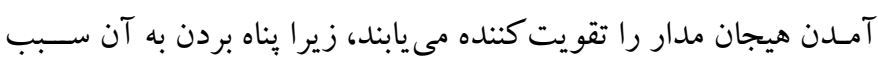

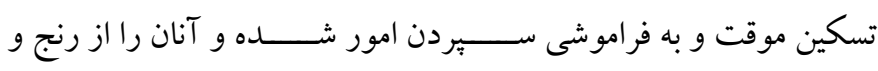

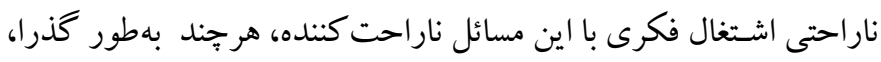

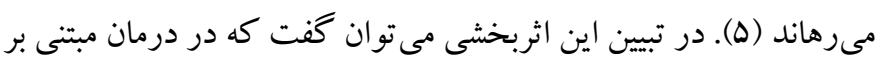

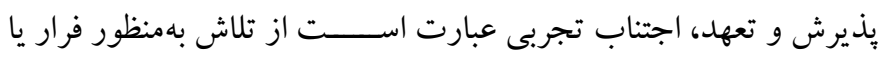

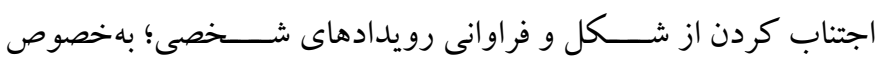

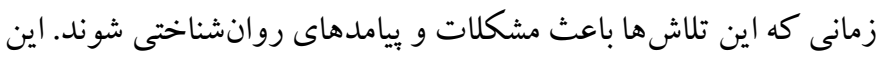

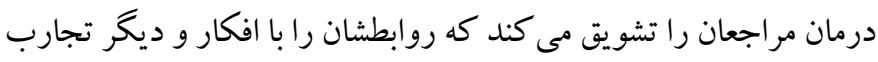

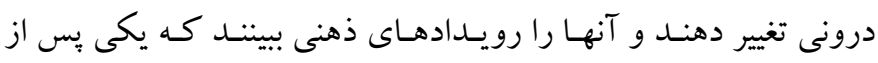

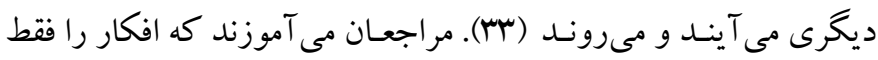

اين مطالعه نشـان داد كه اين درمان موجب افزايش ارزيابى مجدد هيجان

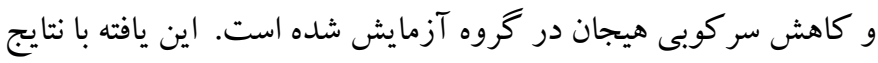

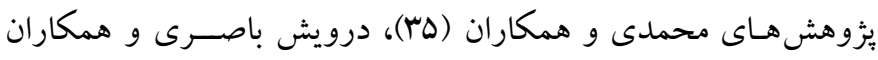

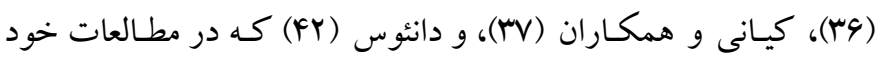
اثربخشى درمان مبتنى بر يذيرش و تعهد بر تنظيم هيجان را نشـان دادند، كاملاً همسو است. در تبيين اين يـافته بايد به فرايندهاى حاكم بر درمان مبتنى بر بذيرش

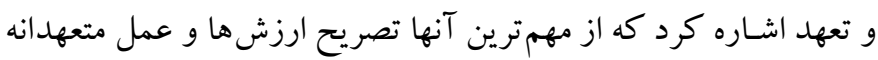

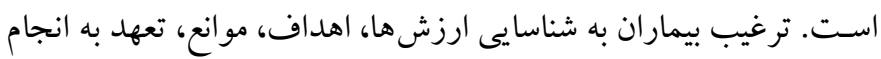

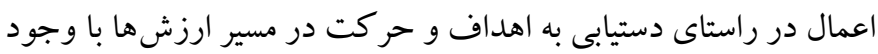

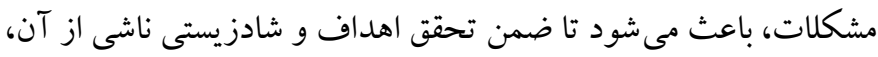

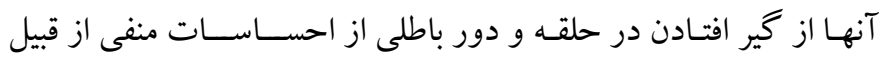

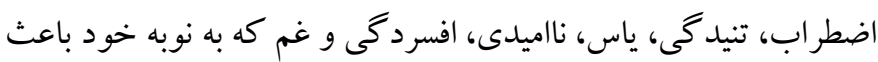

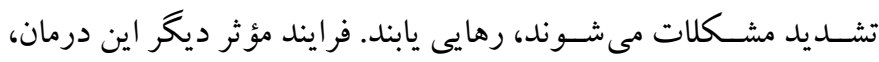
معرفى جايخزين براى مهار گرى يعنى تمايل و بذ يذيرش است. مؤلفه تمايل

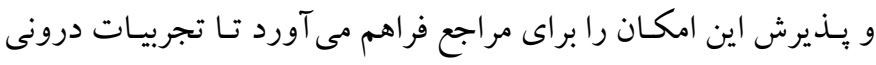

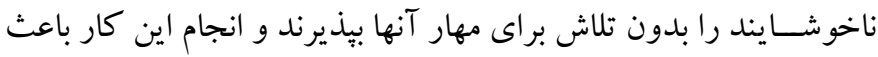

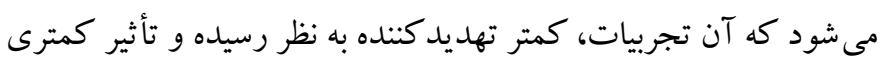

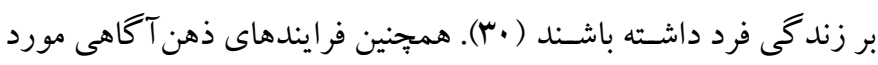

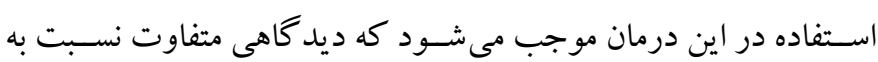
رويدادهاى ذهنى ايجاد شود و به فرد اين اجازه را مىدهد تا رويدادهاى دهى دهى

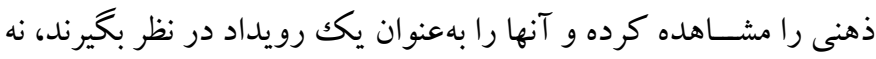

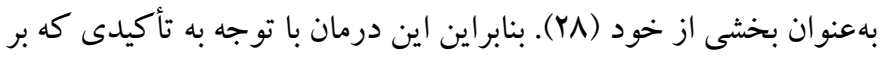

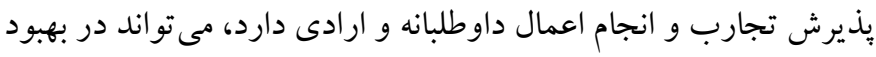
شر ايط و عملكرد افر اد دار ایى اختلالات و بيمارى ها مؤثر واقع شود.

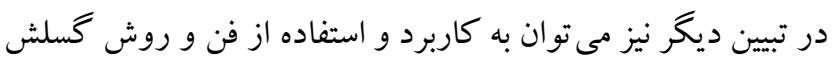

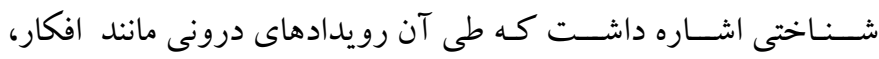

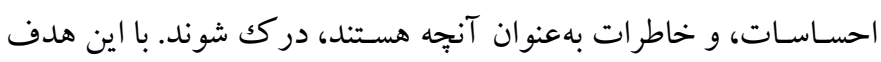

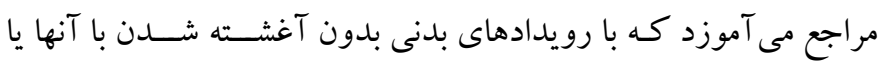

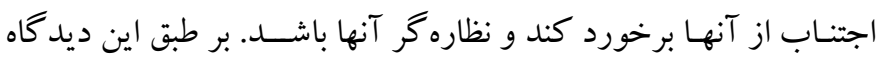

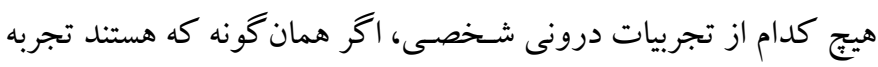
شـوند، بلهور ذاتى براى سلامتى فرد مضر نيستند، بِ نيازى بـ به مهار آنها 
مى كننـد تا مسـئوليت تغييرات رفتارى را بيذيرد (YN). بهطور كل نتايج

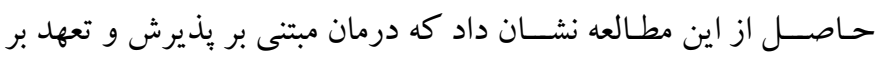

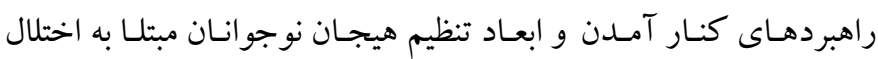

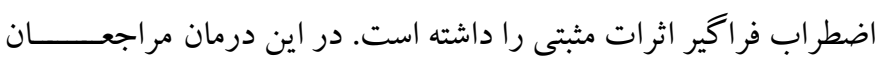

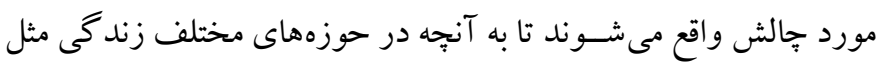

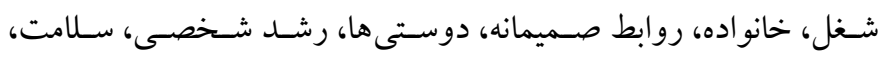
معنويت و امثال آن برايشــان مهم اســت، توجه كنند و از اينرو در مان مان

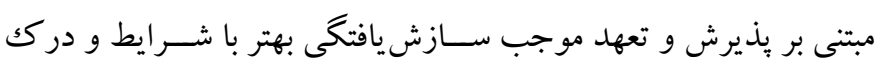

$$
\text { درست وقايع و رويدادها در آنها مىشود. }
$$

اين مطالعه داراى محدوديت هايى نيز بوده اسـت كه از جمله مى توان

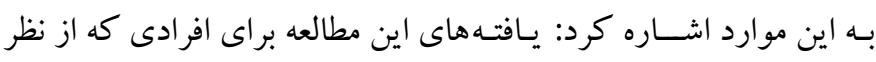

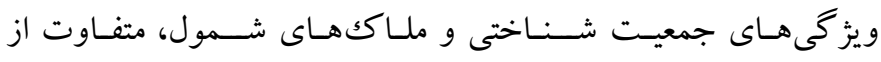

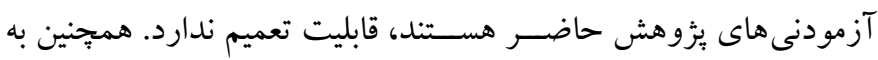

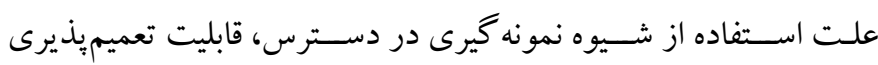

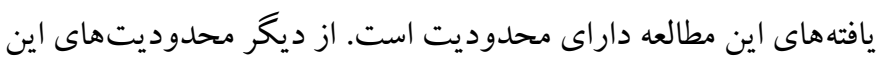

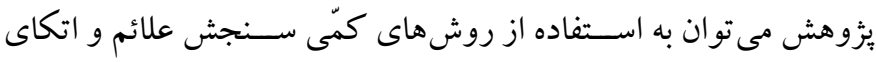

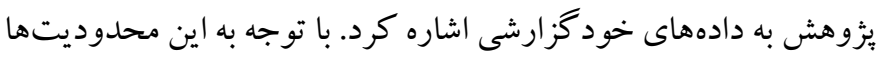

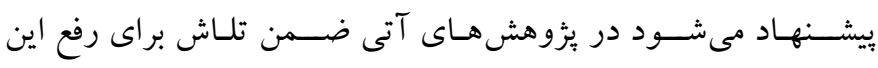

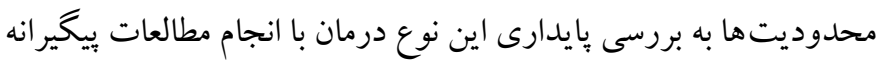

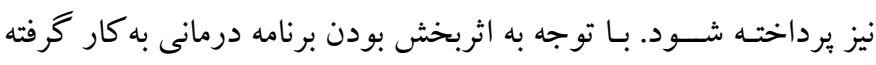

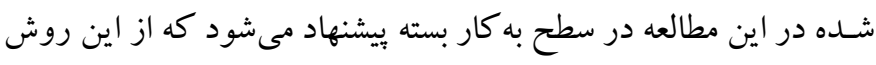
در مراكز درمانى و كلينيككهاى مشاوره و مدارس استفاده شود. همجنين

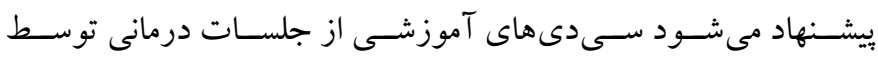

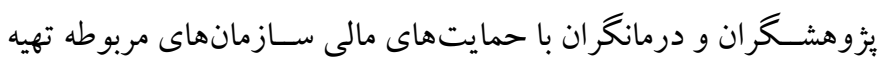

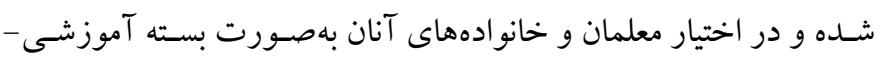

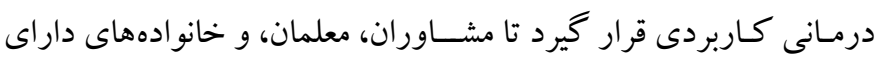

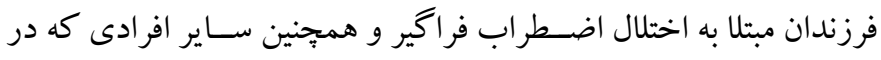

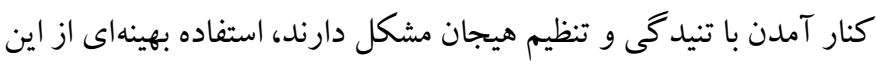
مطالعات و روش درمانى به عمل آورند.

تشكر و قدردانى: اين مطالعه بهصورت مستقل اجرا شده است و حاصل بايان

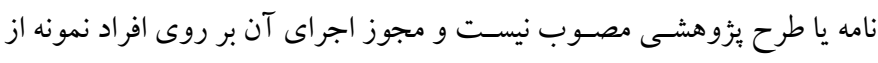

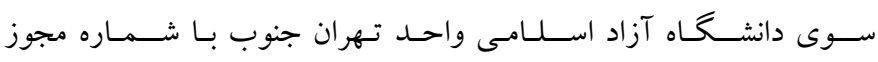

افكار، احساســـات را فقط احساســـات، و خاطرات را فقط خاطــرات

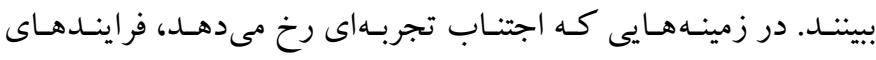

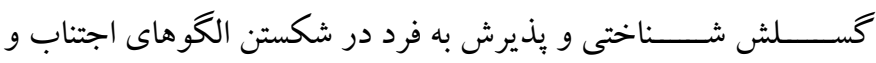

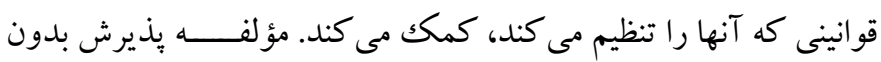

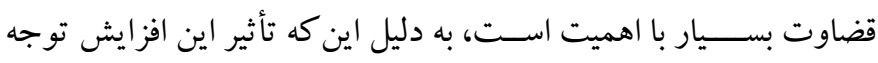

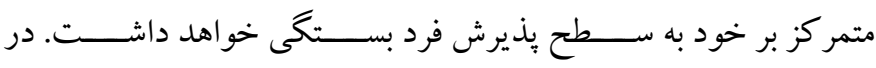

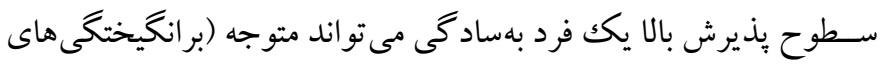
روانى) افكار و احساســات خود شـود، بدون اينكه تلاشى بهمنظور مهار

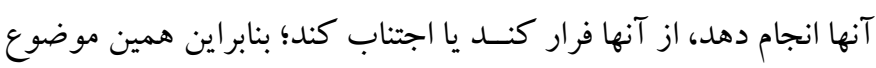

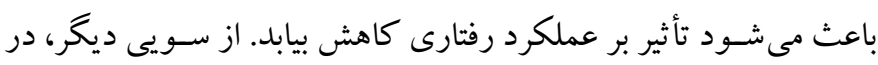

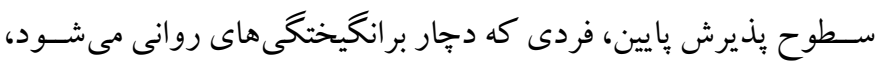

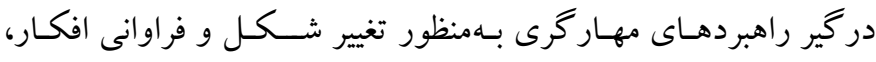

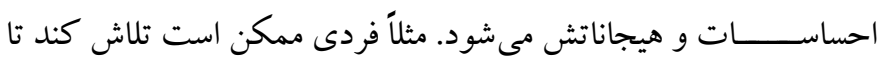

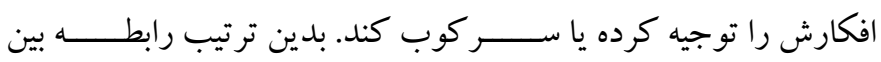

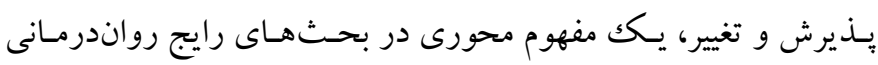

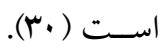

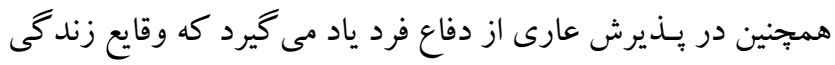

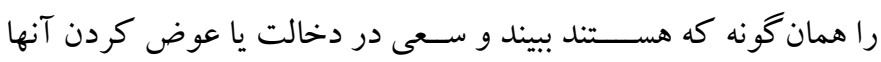
نكند، زيرا افراد زمانى كه با رويدادى غيرقابل تغيير روبرو مى شوند دهن دهار

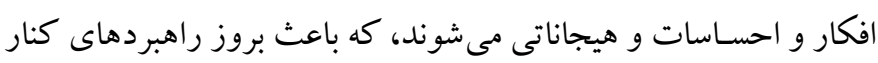

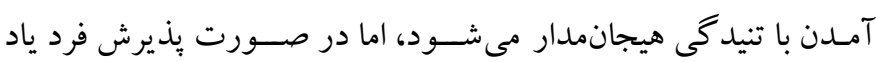

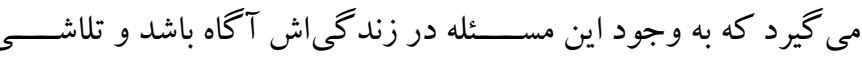

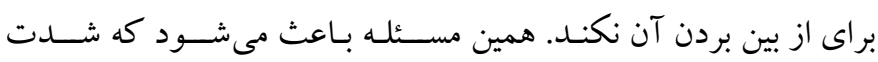

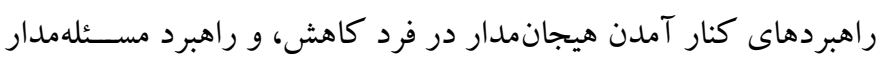

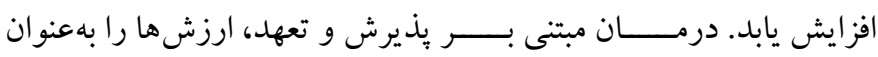

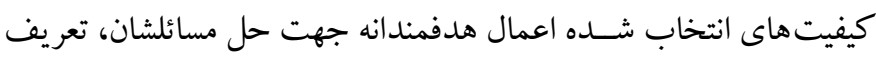

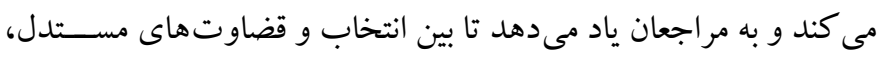

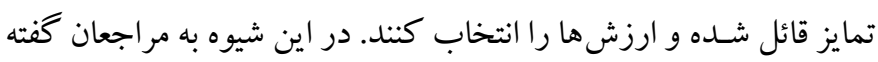

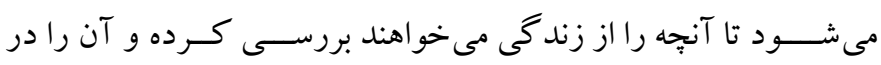

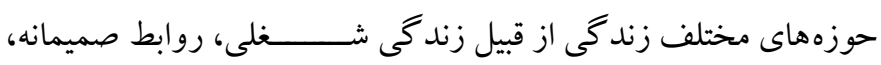

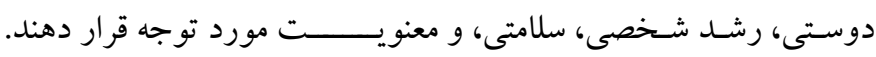

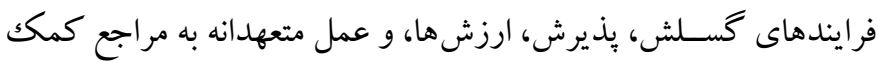


تضاد منافع: هيج گونه تضاد منافعى براى نويسند گان اين مقاله وجود ندارد.

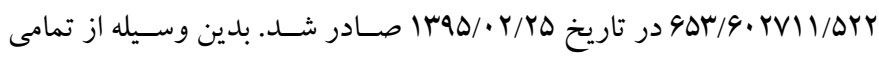
كسانى كه در اجراى اين ئزوهش مشاركت داشتند تشكر و قدردانى مىشود. 


\section{References}

1. Arnett JJ. Adolescence and emerging adulthood. 5th Edition. New Zealand: Pearson; 2012. [Link]

2. Cohen JR, Andrews AR, Davis MM, Rudolph KD. Anxiety and depression during childhood and adolescence: testing theoretical models of continuity and discontinuity. J Abnorm Child Psychol. 2018; 46 (6): 1295-1308. [Link]

3. Kessler RC, Sampson NA, Berglund P, Gruber MJ, AlHamzawi A, Andrade L, et al. Anxious and nonanxious major depressive disorder in the World Health Organization World Mental Health Surveys. Epidemiol Psychiatr Sci. 2015; 24 (3): 210-226. [Link]

4. Akhondzadeh S, Naghavi HR, Vazirian M, Shayeganpour A, Rashidi H, Khani M. Passionflower in the treatment of generalized anxiety: A pilot double-blind randomized controlled trial with oxazepam. J Clin Pharm Ther. 2001; 26 (5): 363-367. [Link]

5. Newman MG, Llera SJ, Erickson TM, Przeworski A, Castonguay LG. Worry and generalized anxiety disorder: a review and theoretical synthesis of evidence on nature, etiology, mechanisms, and treatment. Annu Rev Clin Psychol. 2013; 9: 275-297. [Link]

6. American Psychiatric Association (APA). Diagnostic and statistical manual of mental disorders (DSM-5). Washington, DC: American Psychiatric Pub; 2013. [Link]

7. Rowa K, Antony MM. Generalized anxiety disorder. In: Craighead WE, Miklowitz DJ, Craighead LW, editor. Psychopathology: history, diagnosis, and empirical foundations. John Wiley \& Sons; 2008, pp: 78-115. [Link]

8. Lieb R, Becker E, Altamura C. The epidemiology of generalized anxiety disorder in Europe. Eur Neuropsychopharmacol. 2005; 15 (4): 445-452. [Link]

9. Hamidpour H, Dolatshai B, Pour Shahbaz A, Dadkhah A. The efficacy of schema therapy in treating women's generalized anxiety disorder. 2011; 16 (4): 420-431. [Persian]. [Link]

10. Sharifi V, Amin-Esmaeili M, Hajebi A, Motevalian A, Radgoodarzi R, Hefazi M, et al. Twelve-month prevalence and correlates of psychiatric disorders in Iran: the Iranian Mental Health Survey, 2011. Arch Iran Med. 2015; 18 (2): 76-84. [Link]

11. Gross JJ. Emotion regulation: conceptual and empirical foundations. In: Gross JJ, editor. Handbook of emotion regulation. 2nd ed. New York, NY, US: Guilford Press; 2014, pp: 3-20. [Link]

12. Gross JJ, Jazaieri H. Emotion, emotion regulation, and psychopathology: an affective science perspective. Clin Psychol Sci 2014; 2 (4): 387-401. [Link]

13. Narimani M, Ariapouran S, Abolghasemi A, Ahadi B. The comparison of the effectiveness of mindfulness and emotion regulation training on mental health in chemical weapon victims. Journal of Clinical Psychology. 2010; 2 (4): 61-71. [Persian]. [Link]

14. Kring AM, Sloan DM. Emotion regulation and psychopathology: A transdiagnostic approach to etiology and treatment. Guilford Press; 2009. [Link]

15. Hashemi T, Abdollahi Hersis N, MahmoodAlilo M, Mashinchi Abbasi N. Role of cognitive emotion regulation strategies in symptoms of borderline personality. Journal of Modern Psychological Researches. 2016; 11 (41): 151-168. [Persian]. [Link]

16. Hewitt PL, Flett GL. Perfectionism and stress processes in psychopathology. In: Hewitt PL, Flett GL, editor. Perfectionism: theory, research, and treatment. Washington, DC, US: American Psychological Association; 2002, pp: 255-284. [Link]

17. Navarro V, De la Morena G, González-Arteaga J, Yustres Á, Asensio L. A microstructural effective stress definition for compacted active clays. Geomechanics for Energy and the Environment. 2018; 15: 47-53. [Link]

18. Wills TA, Sandy JM, Yaeger AM, Cleary SD, Shinar O. Coping dimensions, life stress, and adolescent substance use: A latent growth analysis. J Abnorm Psychol. 2001; 110 (2): 309-323. [Link]

19. Mahmoud Alilou M, Khanjani Z, Bayat A. Comparing the coping strategies and emotion regulation of students with symptoms of anxietyrelated emotional disorders and normal group. Quarterly Journal of Child Mental Health. 2016; 3 (1): 41-51. [Persian]. [Link]

20. Khodayarifard M, Mansouri A, Besharat MA, Gholamali Lavasani M. A review of conceptual models for worry and generalized anxiety disorder. Clinical Excellence. 2017; 6 (2): 23-38. [Persian]. [Link]

21. Davoodi A, Neshat Doost HT, Abedi MR, Talebi H. The role of emotion regulation deficits, thought-action fusion and behavioral inhibition in Generalized Anxiety Disorder. scientific journal of ilam university of medical sciences. 2015; 22 (6): 115-124. [Persian]. [Link] 
22. Mohdehi R, E'temadi A. Studying the therapy mediations and the effect of therapy commitment in the reduction of the symptoms of general anxiety disorder. Counseling Culture and Psycotherapy. 2011; 2 (7): 1-30. [Persian]. [Link]

23. Mahmoud-Alilou, Hashemi-Nosratabad, Sohrabi. Effectiveness of combined intervention based acceptance and commitment therapy (ACT) with Exposure techniques on patient's anxiety symptomsintensity and sensitivity dimensions in general anxiety disorder (GAD). Journal of Clinical Psychology. 2016; 8 (3): 61-76. [Persian]. [Link]

24. Zoalfaghari A, Bahrami H, Ganji K. A comparative analysis of acceptance-commitment and cognitivebehavioral interferences effectiveness on generalized anxiety disorder. Journal of Arak University of Medical Sciences. 2018; 20 (12): 24-34. [Persian]. [Link]

25. Evans S, Ferrando S, Findler M, Stowell C, Smart C, Haglin D. Mindfulness-based cognitive therapy for generalized anxiety disorder. J Anxiety Disord. 2008; 22 (4): 716-721. [Link]

26. Reinhold JA, Rickels K. Pharmacological treatment for generalized anxiety disorder in adults: an update. Expert Opin Pharmacother. 2015;16 (11): 1669-1681. [Link]

27. Mogadam N, Amraae R, Asadi F, Amani O. The Efficacy of Acceptance and Commitment Therapy (ACT) on Hope and Psychological Well-being in Women with Breast Cancer under Chemotherapy. Journal of Nursing Education. 2018; 7 (6): 1-8. [Persian]. [Link]

28. Hayes SC, Pistorello J, Levin ME. Acceptance and commitment therapy as a unified model of behavior change. Couns Psychol. 2012; 40 (7): 976-1002. [Link]

29. Asghari M, Faleh kar A, Zaree A, Mirza hoseini F, Amani O. Comparison of the efficacy of acceptance acceptance commitment therapy and electrical stimulation with alternating current on mood symptoms in depressed patients. Iranian Journal of Nursing Research. 2018; 4 (13): 16-23. [Persian]. [Link]

30. Shawyer F, Farhall J, Thomas N, Hayes SC, Gallop $\mathrm{R}$, Copolov D, et al. Acceptance and commitment therapy for psychosis: Randomised controlled trial. $\mathrm{Br}$ J Psychiatry. 2017; 210 (2): 140-148. [Link]

31. Graham CD, Gillanders D, Stuart S, Gouick J. An acceptance and commitment therapy (ACT)-based intervention for an adult experiencing post-stroke anxiety and medically unexplained symptoms. Clin Case Stud. 2015; 14 (2): 83-97. [Link]

32. Behrouz B, Bavali F, Heidarizadeh N, Farhadi M. The effectiveness of acceptance and commitment therapy on psychological symptoms, coping styles, and quality of life in patients with type-2 diabetes. Journal of Health. 2016; 7 (2): 236-253. [Persian]. [Link]

33. Ghorbani M, Amin Pur R. The Effectiveness of acceptance and commitment therapy on stress coping strategies in women with ulcerative colitis. Govaresh. 2015; 20 (1): 34-42. [Persian]. [Link]

34. Shayeghian Z, Hassanabadi H, Aguilar-Vafaie ME, Amiri P, Besharat MA. A randomized controlled trial of acceptance and commitment therapy for type 2 diabetes management: the moderating role of coping styles. PloS one. 2016; 11 (12): e0166599. [Link]

35. Mohammadi L, Salehzade Abarghoei M, Nasirian M. Effectiveness of acceptance and commitment therapy on cognitive emotion regulation in men under methadone treatment. Journal of Shahid Sadoughi University of Medical Sciences. 2015; 23 (9): 853861. [Persian]. [Link]

36. Darvish Baseri L, DashtBozorgi Z. Effectiveness of group therapy based on acceptance and commitment on cognitive emotion regulation and alexithymia of patients with type 2 diabetes. Iranian Journal of Psychiatric Nursing. 2017; 5 (1): 7-14. [Persian]. [Link]

37. Kiani A, Ghasemi N, Pourabbas A. The comparsion of the efficacy of group psychotherapy based on acceptance and commitment therapy, and mindfulness on craving and cognitive emotion regulation in methamphetamine addicts. research on addiction. 2013; 6 (24): 27-36. [Persian]. [Link]

38. Roger D, Jarvis G, Najarian B. Detachment and coping: The construction and validation of a new scale for measuring coping strategies. Personality and Individual differences. 1993; (15): 619-26. [Link]

39. Zahri S. Study of effect self-care education on coping styles in patients with hemodialysis in educational hospitals depended to health ministry in Tehran [MSc Thesis]. [Tehran, Iran]: Iran Medical Sciences University; 1996. [Persian].

40. Gross JJ, John OP. Individual differences in two emotion regulation processes: Implications for affect, relationships, and well-being. J Pers Soc Psychol. 2003; 85 (2): 348-362. [Link]

41. Hosseini F, Khayyer M. Scrutinizing the role of cognitive appraisal in mediating parenting influences on students academic emotions and emotional 
regulatioN. Studies in Learning and Instruction. 2011; 3 (1): 8-10. [Persian]. [Link]

42. Duenas JA. Acceptance and Commitment therapy for adolescent difficulties with emotion regulation: an open trial [P.hD. Thesis]. [Michigan, United States]:
Department of Psychology, Western Michigan University; 2016, pp: 1-63. [Link] 